\title{
Mistrz-nauczyciel i jego powinności. Szkic z pedeutologii historycznej
}

\author{
The Master-teacher and His Duties: \\ A Historical Pedeutology Sketch
}

\begin{abstract}
ABSTRAKT
Przedstawione rozważania wpisuja się w zakres pedeutologii historycznej. Prezentowany szkic poświęcony jest problemowi mistrza-nauczyciela w kontekście rozwoju nauki, badań naukowych i nauczania. Podjęto w nim próbę opisu powinności jakie musi spełniać osoba, którq można określić mianem mistrza. Uczyniono to na wybranych przykładach mistrzów, zasłużonych dla nauki i nauczania, głównie przedstawicieli historii wychowania i pedagogiki. Ich zasługi polegają na stworzeniu szkół naukowych i rozwoju polskich środowisk naukowych. Na potrzeby zaprezentowania zagadnienia wykorzystano zarówno opracowania, jak i materiały archiwalne oraz literaturę pamiętnikarskq. Pomocne były też źródła wywoływane. Wnioski wypływające z analizy źródeł doprowadziły do przekonania, że jednym z najważniejszych cech mistrza-nauczyciela jest rzetelność, przejawiajqca się zarówno w dydaktyce uniwersyteckiej, jak i badaniach naukowych. Rzetelność naukowa jest nie tylko wartościq w ogóle, ale przede wszystkim powinnościq osób, które można nazwać mistrzami. Przy czym należy podkreślić, że artykuł nie pretenduje do miana wyczerpujacego studium, jest jedynie zarysem planowanych dalszych badań nad istota mistrza-nauczyciela i jego znaczenia w dziejach nauki i kultury.
\end{abstract}

StOWA KLUCZOWE mistrz, nauczyciel, publikacje naukowe, recenzje, rzetelność naukowa, pedeutologia historyczna

\section{KEYWORDS}

master, teacher, scientific publications, reviews, scientific reliability, historical pedeutology

SPI Vol. 24, 2021/3

ISSN 2450-5358 e-ISSN 2450-5366 DOI: 10.12775/SPI.2021.3.004

Nadesłano: 21.08.2021 Zaakceptowano: 18.09.2021

Artykuły i rozprawy 


\section{ABSTRACT}

The presented considerations fall within the scope of historical pedeutology. The presented sketch is devoted to the master-teacher problem in the context of the development of science, research and teaching. It attempts to describe the obligations that must be fulfilled by a person in order to be called a master. It was carried out on the basis of selected examples of masters, distinguished for science and teaching, mainly representatives of the history of education and pedagogy. Their merits are based on the creation of scientific schools and contribution to the development of Polish scientific communities. Studies, archival materials and diary literature were all used for the purpose of presenting the issue. The conclusions achieved from the analysis of sources led to the belief that one of the most important characteristics of a master-teacher is reliability, which is manifested in both university teaching and research. Scientific reliability is not only a value in general, but most importantly a duty of people who can be called masters. It must be emphasized that the article does not pretend to be an exhaustive study, it is merely an outline of planned further research on the essence of the master-teacher and its importance in the history of science and culture.

„Choć uczeń może mieć wielu nauczycieli, tylko jeden z nich może zostać wybrany jako mistrz.

Dla ucznia mistrz jest jak tekst, który przykuwa uwagę i w miarę poznania odsłania wszystkie swoje strony". (Sherwin 2005: 70)

„Zawód nauczycielski nie jest rutynowym zawodem «rzemieślniczym», wymaga szczególnej kultury i cech osobowości”.

(Wołoszyn 1998: 319)

\section{Uwagi wstępne}

Prezentowany szkic zawiera refleksje $\mathrm{z}$ deontologii pracownika naukowego i wpisuje się w zakres pedeutologii historycznej. Jest zarysem planowanych dalszych badań nad istotą mistrza-nauczyciela w dziejach nauki i kultury ${ }^{1}$.

1 Tekst nie pretenduje do miana wyczerpującego studium. Jest natomiast zapowiedzią dalszych badań nad tym zagadnieniem. Autorka w niniejszym tekście ze zgromadzonego obszernego materiału do projektu badań wykorzystuje dla przykładu jedynie wybrane źródła i opracowania. 
W uwagach wstępnych chcę wskazać na konteksty interpretacji takich relacji jak: mistrz - uczeń czy mistrz - nauczyciel. Najczęściej w literaturze naukowej spotkamy dwa ujęcia mistrzostwa: relacja mistrz - uczeń/uczniowie oraz mistrz - jego dzieła (Jadczak: 1992, 1997; Zgorzelski 1983; Szlachta 1984; Szczepański 1994; Jadacki 2016; Karolewicz 2020; Marynowicz-Hetka 1997; Szulakiewicz 2010, 2014a, 2014b). Najprościej rzecz ujmując, we wskazanych publikacjach ich autorzy dowodzą, że ktoś jest mistrzem, gdyż był twórcą szkoły naukowej i wykształcił grono uczniów lub ktoś zostaje nazwany mistrzem ze względu na wybitne dzieło/dzieła, których jest autorem. Źródłem, które znakomicie ukazuje szkoły naukowe i ich twórców jest wydawnictwo pt. Uczeni Polscy XIX i XX wieku (Śródka 19941998). W wydawnictwie tym odnajdujemy wykaz uczniów przywołanych w tej publikacji uczonych, których niewątpliwie można nazwać mistrzami. Z kolei wśród uczniów tychże uczonych dostrzec można nazwiska kolejnych mistrzów. Można by wręcz rzec, że mistrzostwo to jest przekazywane z pokolenia na pokolenie, a uczniowie otrzymują spadek po swoich nauczycielach-mistrzach. Innym ważnym źródłem, które zawiera opisy tego, co zawdzięczamy mistrzom-nauczycielom, jest literatura pamiętnikarska, zarówno ta opublikowana, jak i znajdująca się w spuściznach archiwalnych uczonych. Mówiąc o mistrzu-nauczycielu warto przynajmniej zasygnalizować co jest istotą mistrzostwa w zawodzie nauczyciela i jakie warunki temu sprzyjają. Ważnym aspektem bycia zarówno nauczycielem, jak i mistrzostwa naukowego, jest autorytet, który jest istotny w różnych obszarach aktywności. W tej kwestii warto oddać głos Henrykowi Rowidowi, który wyróżnia dwa rodzaje autorytetu: wyższy i niższy (Rowid 1957: 257 i n.). Istotnym głosem w spojrzeniu na zagadnienie autorytetu jest pogląd Hansa-Georga Gadamera, który mówiąc o autorytecie łączy go z wolnością (Gadamer 2011: 145-153). Przy czym wskazuje na mylenie niekiedy autorytetu $\mathrm{z}$ autorytaryzmem.

Problem mistrzostwa w nauce i nauczaniu wpisuje w zagadnienie etyki $\mathrm{w}$ zawodzie pracownika nauki. Tadeusz Czeżowski mówiąc o etyce zawodu nauczyciela (deontologii pracownika naukowego) wymienił kilka zasad, które powinny być spełnione: (1) stosunek pracownika nauki do uprawianej przez siebie nauki, tj. sumienność w badaniach naukowych i podawaniu ich wyników, (2) stosunek do kolegów i współpracowników, (3) stosunek do 
uczniów - obowiązkowość i opieka, (4) stosunek do społeczeństwa i władz państwowych (Czeżowski 1967: 118). Przykłady mistrzostwa można ukazać w świetle wspomnień, źródeł archiwalnych, ale również - a może zwłaszcza - recenzji zawartych w spuściznach nauko$w_{y y c h}^{2}$ oraz wykorzystując opracowania naukowe i recenzje. Także księgi jubileuszowe są bardzo często wyrazem ukazywania przykładów mistrzów-uczonych, którzy tworzyli szkoły naukowe, ale także wyrazem pamięci indywidualnej i zbiorowej.

W niniejszym szkicu zwrócę uwagę, podając przykłady mistrzów-nauczycieli, na dwa zasadnicze problemy: (1) jakie powinności są nieodłącznym elementem bycia mistrzem-nauczycielem w świetle wybranych źródeł oraz (2) jakie zasady badań naukowych i kryteria oceny prac naukowych wynikają $z$ analizy biografii wybranych uczonych, a zarazem mistrzów-nauczycieli. Sygnalizując w swych rozważaniach podnoszone kwestie, odnoszę się głównie do „spuścizny naukowej” 3 pedagogów i historyków wychowania i ich idei zawartych w opracowaniach naukowych oraz we wspomnieniach byłych uczniów. Można ogólną intencję niniejszej wypowiedzi zakreślić pytaniem: co my, przedstawiciele danej dyscypliny naukowej, którą prezentujemy, zawdzięczamy wybitnym mistrzom-nauczycielom?

\section{Znaczenie nauczycieli-mistrzów w nauczaniu i nauce}

Zagadnie znaczenia nauczycieli-mistrzów będzie zasygnalizowane w świetle opracowań oraz tych przekazów, które zostały zapisane w pamięci uczniów i współpracowników.

Mówiąc o różnorodnych kontekstach mistrzostwa, można się posłużyć rozróżnieniem Jacka Jadackiego, który określa istotę mistrza-nauczyciela ${ }^{4}$. Stwierdza, że mistrzem jest ktoś w pewnej dziedzinie

2 Przygotowując prace na temat rozwoju polskiej historii wychowania, sięgałam do dokumentacji przewodów doktorskich i habilitacyjnych, w których znajdują się recenzje wybitnych mistrzów. Ten rodzaj źródła wart jest osobnego wykorzystania dla opracowania niniejszego tematu.

3 Mówiąc o spuściźnie, mam na myśli zasady i idee, którymi kierowali się w swej działalności naukowej i nauczycielskiej wybitni mistrzowie, a które zostały odnotowane w opracowaniach i wspomnieniach ich uczniów oraz współpracowników.

4 Wiele intersujących idei na temat mistrza-nauczyciela znajdujemy w publikacji pt. Mistrz-uczeń. Wyobrażenia czy rzeczywistość, czyli o tworzeniu szkót naukowych (Marynowicz-Hetka 1997). 
naukowej lub czyimś mistrzem (Jadacki 2016: 77-81). Według tego autora mistrzem jest ktoś, kto jest zarazem specjalistą w pewnej dziedzinie i znakomitym nauczycielem w tej dziedzinie. Tak więc być dla kogoś nauczycielem, może oznaczać być czyimś mistrzem. Naturalnie nie jest to reguła, nie zawsze musi tak być. Co zatem zawdzięcza się nauczycielom-mistrzom? Dla egzemplifikacji zagadnienia warto przywołać przykłady działalności wybitnych uczonych, w świetle wypowiedzi tych uczniów, którzy zaświadczają jaką rolę odegrali w ich życiu nauczyciele, których oni nazywają swoimi mistrzami.

Zapewne trudno $\mathrm{w}$ polskiej humanistyce odnaleźć drugiego takiego mistrza, o którym wypowiedziano tyle słów wdzięczności i obdarowano medalem z napisem „Uczniów miłość i wdzięczne przywiązanie”. Mam na myśli Kazimierza Twardowskiego. Na ten temat istnieje bogata literatura, a relacja mistrz i jego uczniowie została zaprezentowana m.in. w publikacjach Ryszarda Jadczaka pt. Mistrz i jego uczniowie oraz Władysławy Szulakiewicz zawartych w bibliografii niniejszego artykułu. Oceny jego pracy jako nauczyciela i badacza wypowiedziane przez jego uczniów ilustrują doskonale stosowanie przez niego mistrzowskiej metody naukowej, a także metod nauczania. Opis mistrzostwa Kazimierza Twardowskiego zawarty został w licznych wspomnieniach zebranych i opublikowanych m.in. przez Jadczaka (1992: 472-491) oraz tekstach jego uczniów rozsianych w licznych innych wydawnictwach ${ }^{5}$.

Ze szkoły Twardowskiego wyszło wielu kolejnych mistrzów, których można określić mianem następców jego osoby i jego mistrzostwa (Woleński 1985; Szulakiewicz 2010, 2014b), przedstawicieli różnych dyscyplin naukowych, w tym także pedagogiki i historii wychowania.

Dla przykładu można wymienić Stanisława Łempickiego, twórcę lwowskiej szkoły historii wychowania, także ucznia Twardowskiego. Jego dzieło badawcze i nauczycielskie przedstawił Łukasz Kurdybacha, nazywając go swym mistrzem. Kurdybacha doceniał jego metody nauczania oraz opiekę nad studentami, która wyrażała się także m.in. w trosce o ich sytuację materialną i zdrowotną. Odniósł się również w swych wywodach do działalności nauczycielskiej. Wykłady Łempickiego oceniał następująco: „W przygotowanych starannie wykładach przedstawiał nie tylko dotychczasowy stan

5 Dla przykładu można wymienić m.in. Leopolda Blausteina, Stanisława Łempickiego, Kazimierza Sośnickiego i innych. 
badań, ale zwracał uwagę na kwestie sporne, wysuwał zagadnienia, które w przyszłości powinny być opracowane, zachęcał dyskretnie słuchaczy do podjęcia samodzielnych wysiłków badawczych, pobudzał do myślenia, wzniecał zainteresowania. Metoda ta wypływała z jego głębokiej wiary, że w każdym człowieku drzemie talent twórczy, a zadanie wychowawcy na szczeblu uniwersyteckim polega na wydobyciu z każdego studenta jego najlepszych cech, na ugruntowaniu zaufania w jego własne siły i zdolności umysłowe. W oparciu o te przekonania udawało mu się osiągnąć często zdumiewające rezultaty" (Kurdybacha 1947: 374). Podobnie oceniał sposób egzaminowania, stwierdzając, że podczas egzaminu „Prof. Łempicki potrafil wyciągnąć pewne określone minimum z każdego niemal studenta i dlatego stopnie niedostateczne były u niego rzadkością. Jeśli był zmuszony czasami je stawiać, odczuwał je bodaj równie boleśnie jak i niefortunny kandydat" (Kurdybacha 1947: 375). Jako nauczyciel akademicki wykazywał się wielką tolerancją wobec inności poglądów politycznych czy religijnych lub światopoglądowych ${ }^{6}$. Kurdybacha podkreślał, że Łempicki potrafił skupiać wokół siebie uczniów i współpracowników, był otwarty dla szukających wsparcia naukowego, ale i rady w sprawach osobistych, codziennych, a ważnych dla każdego człowieka.

Wśród mistrzów-nauczycieli, którzy odegrali dużą rolę w rozwoju pedagogiki jako dyscypliny, a przede wszystkim w kształceniu młodych adeptów nauki, warto wymienić Bogdana Nawroczyńskiego (1882-1974) (Kupisiewicz 2010; Szulakiewicz 2017). W piękny sposób o mistrzostwie Nawroczyńskiego mówił Tadeusz Wiloch, tytułując swoją wypowiedź Wymagat tylko(?) rzetelności naukowej... (Wiloch 1996: 129-133). Jako współpracownik, a jednocześnie młody adept nauki przygotowujący prace awansowe, tak pisał o Nawroczyńskim: „W postawie sędziwego Profesora widać było wciąż radość z tego, że swoją pracą pedagogiczną i badawczą rzeczywiście służymy Rzeczypospolitej. I było to chyba równie wartościowe, jak wzór własnej pracy mistrza, wykonanej nie tylko dla własnej przyjemności, lecz i na użytek publiczny, szczególnie dla studentów i nauczycieli” (Wiloch 1996: 131). Opisując mistrzostwo Nawroczyńskiego, zasady pracy naukowej stosowane podczas seminariów i spotkań naukowych,

6 Szerzej na ten temat: Szulakiewicz (2012). 
dodawał: „Profesor B. Nawroczyński był mistrzem i w swojej karierze nauczyciela gimnazjalnego, jak i współtwórcy polskiej koncepcji programowej $\mathrm{w}$ resorcie edukacyjnym i przede wszystkim w całej działalności uniwersyteckiej” (Wiloch 1996: 132). Na koniec swych uwag o Profesorze wspominał recenzje swoich prac, zwłaszcza uwagi w odniesieniu do pracy habilitacyjnej, gdyż otrzymał od mistrza wiele uwag krytycznych, ale podkreślił, że na Nawroczyńskiego nie można było się gniewać, bo był ,tolerancyjnym mistrzem, wymagał tylko rzetelności naukowej” (Wiloch 1996: 133). Również Czesław Kupisiewicz we wspomnieniach przypomina jaką rolę odegrał Nawroczyński w jego rozwoju naukowym. Przypominał recenzje swoich prac wykonane przez tego uczonego, bowiem tenże kilka razy był recenzentem jego publikacji w związku $\mathrm{z}$ awansami naukowymi (Archiwum PAN, Warszawa, sygn. III-213, Spuścizna B. Nawroczyńskiego; Szulakiewicz 2017). Kupisiewicz przypomniał nawet słowa, od których zaczynała się recenzja jego pracy doktorskiej: „Nie wystarczy siąść przy fortepianie, aby grać jak Paderewski”. I dalej: „Gdybym nie wiedział (...), że autor zna niemiecki, to nie miałbym do niego pretensji za cytowanie prac Herbarta z polskich tłumaczeń, notabene często błędnych, a nie $z$ oryginału. To samo dotyczy Deweya, aczkolwiek w tym przypadku polscy tłumacze spisali się znacznie lepiej niż przy Herbarcie" (Kupisiewicz 2009: 34). Nie tylko ta zacytowana opinia, ale i inne opinie oceniające autorstwa Nawroczyńskiego nie były pozbawione uwag krytycznych dotyczących najczęściej języka ocenianych prac, logiki narracji i podstaw źródłowych. Znakomicie potrafił odczytywać styl pisarski ocenianych autorów. Sporządzone przez Nawroczyńskiego recenzje cechowało docenianie klasycznych wartości stanowiących o pracy naukowej, czyli takich jak rzetelność i sumienność autorów, próba wniesienia czegoś nowego do nauki. Nic dziwnego, był przecież uczniem Twardowskiego. Dlatego lektura jego recenzji może przynieść korzyści także współczesnym pedagogom zabierającym głos w sprawie awansów naukowych. Trzeba podkreślić, że przedstawione uwagi Nawroczyńskiego zawarte w recenzjach i stwierdzenia oceniające znajdujące się $\mathrm{w}$ jego opiniach mają także znaczenie dla współczesności, bowiem jakże wiele w obiegu czytelniczym jest prac, których ze względu na liczne błędy nie można polecać 
studentom i nie powinno się ich cytować, gdyż są one zaprzeczeniem przestrzegania zasad rzetelnego pisarstwa naukowego ${ }^{7}$.

Innym przykładem $\mathrm{w}$ zakresie intersującego nas tematu niech będzie przypomnienie dzieła naukowego Kamilli Mrozowskiej (1917-2002), uczennicy m.in. Wacława Tokarza, Marcelego Handelsmana, Wandy Bobkowskiej, Jana Hulewicza, wybitnej polskiej historyk wychowania ${ }^{8}$. Zasłużyła się w dziele rozwoju polskiej historii wychowania jako badaczka, nauczyciel i wychowawca licznych pokoleń nauczycieli, w tym nauczycieli akademickich i badaczy (Bartnicka 2002: 3-5; Dybiec 1999: 39-42; Szulakiewicz 2008: 658-672). O nauczycielach, którzy odegrali szczególną rolę w ukształtowaniu jej osobowości, światopoglądu i stosunku do wykonywanych zadań, mówiła ona bardzo pięknie w jednej ze swoich wypowiedzi (Mrozowska 1984: 57-69). Swoje wspomnienie rozpoczęła od nauczycieli najniższego szczebla kształcenia. Przypominała nauczycieli i szkołę, która wprowadzała uczniów w świat wartości i norm moralnych. „Świat norm moralnych jaki nam w szkole stworzono, wspominała, był światem oczywistym, że dobre jest dobre, że złe jest złe i nie ma tu żadnego kluczenia, przebierania, ćwierćtonów prawdy. Był to czarno-biały, dobry i pewny świat. Kazali nam wierzyć w niepodzielność wartości i dlatego miałyśmy młodość jasną, spędzoną w poczuciu bezpieczeństwa i ładu świata. Czyli w tym, co musi młodziutki człowiek, aby wrósł prosto zanim jego umysł dojrzeje do wątpliwości i nauczy się je rozstrzygać" (Mrozowska 1984: 62). Takimi zasadami kierowała się w swej działalności naukowej i nauczycielskiej. Potwierdzili to piszący o Pierwszej Damie Historii Wychowania. Dla przykładu Kalina Bartnicka charakteryzując jej twórczość naukową zauważyła, że „Rozprawy i monografie Kamilli Mrozowskiej oparte są na gruntownych badaniach źródłowych, odznaczają się doskonałym warsztatem naukowym oraz pięknym, klarownym wykładem. Dobrze rozumiała wartość materiałów źródłowych, tak w kształceniu, jak i w pracy badawczej. Lubiła i ceniła pracę ze źródłami” (Bartnicka 2002: 5). Zdaniem Bartnickiej, jej opracowania materiałów źródłowych są przykładem rzetelności naukowej. Autorka tej wypowiedzi dała pogląd na

$7 \mathrm{Na}$ okładkach tych prac niekiedy znajdują się nie opinie, ale raczej hymny pochwalne recenzentów na ich temat.

8 Profesor Czesław Majorek nazywał Kamillę Mrozowską Pierwszą Damą Polskiej Historii Wychowania. 
temat jaką była osobą w życiu codziennym, stwierdzajac: „Profesor Kamilla Mrozowska była osobą bardzo życzliwą ludziom. Jako pedagog i opiekun naukowy była sumienna i odpowiedzialna, ale wyrozumiała i tolerancyjna dla cudzych poglądów. Była odważna, ale i rozważna $\mathrm{w}$ formułowaniu własnych sądów i wypowiadaniu opinii. Miała poczucie humoru, była towarzyska i potrafiła cieszyć się życiem, mimo swojej niełatwej sytuacji osobistej i ciężkich kłopotów ze zdrowiem. Snuła plany naukowe, interesowała się i przejmowała życiem swojego kraju i narodu" (Bartnicka 2002: 5). Jej szczególny szacunek do źródeł historycznych podkreślił także Julian Dybiec w opracowaniu z okazji odnowienia jej doktoratu. Ukazując jej działalność naukowo-dydaktyczną w Uniwersytecie Jagiellońskim i główne kierunki badań, napisał: „W środowisku naukowym krakowskim, ale chyba i w skali ogólnopolskiej jest Profesor Mrozowska jednym z najwybitniejszych wydawców źródeł historycznych. Jak się wydaje, ta forma działalności jest rezultatem Jej doświadczeń i refleksji. Ktoś, kto z bólem i bezradnością obserwował, jak płonęły zbiory Biblioteki Narodowej i innych kolekcji w Warszawie w czasie II wojny światowej...” (Dybiec 1999: 40). Przypomniał również jej zasługi w kształceniu akademickim: „W pamięci licznej rzeszy pedagogów i historyków cieszy się uznaniem świetnego wykładowcy i wychowawcy. Jako rzadki przykład samodyscypliny i poczucia obowiązku można podać, iż tuż przed przejściem na emeryturę podjęła się jeszcze przygotowania nowego i oryginalnego kursu wykładów dla studentów, wiedząc, że oznacza on jedynie zakończenie pracy dydaktycznej i nie będzie już w ogóle wykorzystywany" (Dybiec 1999: 42).

Znacząca postacią w dziejach środowiska naukowego Lublina (KUL) była Profesor Teresa Kukołowicz (1925-2014), która budowała środowisko naukowe Katolickiego Uniwersytetu Lubelskiego, pełniąc różne funkcje administracyjne, prowadząc badania naukowe i zajęcia dydaktyczne. Opinie o Niej jako mistrzyni wydała s. Maria Opiela, która była jej studentką i doktorantką (Opiela 2018: 97-116 oraz Wspomnienie) $)^{9}$. Siostra Opiela, będąc uczennicą prof. Kukołowicz, doświadczyła, że dzięki jej pracy organizacyjnej, naukowo-badawczej

$9 \quad$ Siostra Maria Opiela przygotowując swoje wspomnienie korzystała także $\mathrm{z}$ licznych notatek z konsultacji odbytych u Profesor Kukołowicz w latach 1990-1995. 
i dydaktycznej, ona oraz inni studenci mieli możliwość nie tylko kształcenia się w nurcie personalizmu pedagogicznego, ale też kształtowania swej osobowości, myślenia i rozumienia rzeczywistości oraz uświadamiania sobie własnej roli w tej rzeczywistości. Pani Profesor jako nauczyciel akademicki oddziaływała swym przykładem.

Zdaniem s. Opieli, Profesor Kukołowicz ,jako osoba doświadczona życiem, jednoznaczna w swoich poglądach, prawa i otwarta na każdą osobę, była osobą o wielkiej wiedzy i mądrości, którą określała jako umiejętność życia” (Opiela, Wspomnienie). Wspominając swoją pracę nad myślą pedagogiczną Bojanowskiego, autorka podkreśliła, że Kukołowicz miała osobisty wpływ na jej interpretacje i metodologiczne podejście do tematu. „Zaiste po mistrzowsku - napisała s. Opiela we wspomnieniu - dyskretnie i z dalekowzrocznym spojrzeniem doradzała $\mathrm{w}$ sformułowaniu tematu, sugerowała współpracę czy konsultacje z osobami specjalizującymi się w danej dziedzinie" (Opiela, Wspomnienie). Zachęcała do rzetelnej refleksji nad szerzącymi się różnymi nowymi koncepcjami pedagogiki. Profesor Kukołowicz, w opinii s. Opieli, doceniała wartość bezpośrednich relacji międzyosobowych, była wzorem naukowca o jednoznacznie chrześcijańskim profilu wartości (Opiela, Wspomnienie).

We wspomnieniach s. Opieli była ona osobą życzliwą dla wszystkich, chociaż bardzo wymagającą, umiejętnie budowała klimat wspólnoty. Miała wielki szacunek dla każdego człowieka, była dyskretna i nie osądzała niepowodzeń, lecz wytrwale poszukiwała najlepszych rozwiązań. Siostra Opiela w końcowej części swych wspomnień o Profesor Kukołowicz napisała: „W ten sposób jak matka (mówiliśmy: «Matka Teresa») i prawdziwy Mistrz ukazywała drogę, towarzyszyła, pomagała, kierowała do specjalistów, wspierała dążenie do poszukiwania prawdy i dobra. Pozostawiając możliwość rozwijania samodzielności, przygotowywała nas do odpowiedzialnego zaangażowania zarówno w teoretyczne dociekania, jak i praktyczne działania pedagogiczne w przyszłości” (Opiela, Wspomnienie).

Niezwykłą osobą w dziejach polskiej historii wychowania był Profesor Czesław Majorek (1938-2002), uczony związany z krakowskim środowiskiem, znany $\mathrm{w}$ środowisku ogólnopolskim, ale i światowych kręgach badaczy historii wychowania jako działacz International Standing Conference for the History of Education (ISCHE) i uczestnik licznych konferencji międzynarodwych 
$\left(\right.$ Ruta 2003, 2008) ${ }^{10}$. Był uczniem Kazimierza Sośnickiego i Mariana Tyrowicza ${ }^{11}$. Profesor regularnie wyjeżdżał na badania naukowe i na zajęcia dydaktyczne do zagranicznych ośrodków naukowych. Uczestniczył aktywnie w wielu konferencjach międzynarodowych, publikował referaty i artykuły w językach obcych, popularyzował w świecie polską historię wychowania, wypowiadając się wielekroć w kwestiach metodologicznych. Jako nauczyciel akademicki, uczony i badacz, uczył właściwego stosunku do uprawianej dyscypliny, co nazywał „samoświadością uprawianej dyscypliny”. Wielokrotnie wypowiadał się na temat metod i przedmiotu badań historii wychowania (Majorek 1987: 177-190; 1993: 110-124; 2002: 44-60). Rozumienie historii wychowania to według Majorka konieczność stawiania sobie pytań: W jakim celu, po co, dla kogo, czy i komu jestem potrzebny? Co mogę zaoferować innym? (Majorek 1993: 112). Odpowiedzi na te pytania służyły przede wszystkim integracji poznania historycznego i pedagogicznego. Patrzył na to zagadnienie z perspektywy definicyjnego ujmowania przedmiotu badań historii wychowania i pedagogiki (Majorek 1987: 177-190). Brak precyzji w definiowaniu przedmiotu badań zarówno pedagogiki, jak i historii wychowania określił jak swoistego rodzaju uniwersalizm i pytał: „Czy wobec uniwersalizmu historii i pedagogiki, uniwersalizmu wynikającego z przedmiotu badań, można oczekiwać jednoznacznych ich definicji? Czy mnogość zjawisk historycznych i wychowawczych da się ująć w paradygmat przystający do reguł naukowej ścisłości?” (Majorek 1987: 178). Zdaniem Profesora, odpowiedź pozytywna na te pytania przeczyłaby zdrowemu rozsądkowi, a to z tej prostej przyczyny, że ani faktów historycznych, ani faktów wychowawczych nie potrafimy wyizolować czy też policzyć” (Majorek 1987: 178).

10 Szerzej na temat drogi naukowej i dorobku publikacyjnego Czesława Majorka zob. W stużbie szkoty i nauki. Księga poświęcona Profesorowi Czestawowi Majorkowi, red. Z. Ruta, R. Ślęczka, Kraków 2003. Przywołując zasady pracy naukowej, którymi kierował się Profesor Majorek, przytaczam fragmenty mojego referatu pt. „Czego nas uczył Profesor Czesław Majorek”, wygłoszonego podczas seminarium w Krakowie, zorganizowanego przez Katedrę Historii Oświaty i Wychowania Uniwersytetu Pedagogicznego im. KEN w 10. rocznicę śmierci Profesora, w dniu 26.09.2012 roku. Tekst nie był publikowany.

11 Recenzentami rozprawy doktorskiej Czesława Majorka byli Łukasz Kurdybacha i Tadeusz Słowikowski. 
Profesor Majorek głosił pogląd, że dziejowy rozwój, a i współczesne oblicze historii wychowania, należy sytuować na dwóch płaszczyznach, mianowicie na gruncie ewolucji nauki historycznej oraz w nurcie rozwoju pedagogiki naukowej. Podnosząc kwestie badań historycznych, a zarazem sytuując historię wychowania w płaszczyźnie historycznej, stwierdzał: „Nie ulega zatem wątpliwości uznanie historii wychowania za istotny składnik historiografii w ogóle" (Majorek 1987: 180). Z tego też powodu zalecał, aby historię wychowania uznać nie tylko jako subdyscyplinę historyczną, ale jako czynnik integrujący inne działy historiografii. $Z$ kolei analizując dzieje rozwoju pedagogiki podkreślał, że niezrozumiała w zupełności jest postawa pedagogów głoszących ahistoryczność pedagogiki. Wynika to jego zdaniem ze skrajnego, źle pojmowanego empiryzmu przedstawicieli nauk pedagogicznych. $Z$ rozważań tych wyprowadził wniosek, że relacja historii wychowania do pedagogiki i historii nie oznacza, że funkcjonuje ona tylko dzięki akceptacji wzajemnej. Przekonywał, że jest ona samodzielną dyscypliną w gronie nauk humanistycznych. Dodatkowo praktyka badawcza prowadzona przez historyków wychowania potwierdza jej aplikacyjne walory, ale jednocześnie dowodzi faktu, że ma ona samodzielny obszar badawczy. Kwestię tę ujął następująco: „Nie zawłaszcza (...) pola badawczego żadnej z dyscyplin spokrewnionych, a raczej służy im w adekwatnej rekonstrukcji tych zakresów badanej rzeczywistości, które stanowią podstawowy ich przedmiot" (Majorek 1987: 183). Tak jest, jego zdaniem, w przypadku nauki historycznej, tak również jest w przypadku nauk pedagogicznych. Pedagogika zorientowana w swych poszukiwaniach na empirię daje odpowiedź na pytania: Jak jest i jak być powinno? To, zdaniem Majorka, nie wystarczy, gdyż potrzebna jest odpowiedź na pytanie: Dlaczego tak jest? I tu pedagodzy muszą szukać pomocy u historyków wychowania, „aby uzyskać odpowiedź na dręczące każdego refleksyjnego badacza pytania, dlaczego tak jest i gdzie tkwią źródła naszego hic et nunc" (Majorek 1987: 183). W tekstach z zakresu metodologii badań wypowiedział wiele cennych uwag na temat metodologicznych aspektów badań historyczno-oświatowych. Wskazał jasno na konieczność właściwego rozumienia badań historycznych w kontekście nauk pedagogicznych. Kreśląc wizerunek mistrzostwa profesora Majorka, warto nadmienić, że ważnym składnikiem budowania „samoświadomości uprawianej 
dyscypliny" (oprócz rozumienia przedmiotu badań i metodologii badań) była jego zdaniem aktywność historyków wychowania na rzecz popularyzacji osiągnięć naukowych, co łączyło się z troską o adresata. Każdy historyk wychowania musi bowiem mieć na względzie potencjalnego czytelnika i zdawać sobie sprawę z jego potrzeb i zainteresowań (Majorek 2002: 59-60). Prace z zakresu historii wychowania mają wspomagać wyjaśnianie współczesnych zjawisk pedagogicznych, dlatego ich autorzy nie mogą im nadawać jedynie charakteru dzieła historycznego. To także łączy się z używaniem właściwego i zrozumiałego języka dla współczesnych czytelników. Historyk wychowania, w opinii Profesora Majorka, musi pamiętać, że adresaci jego dzieła oczekują nie tyle informacji o przeszłości, ale i o genezie teraźniejszości. Dzięki temu jego praca będzie pełnić nie tylko rolę poznawczą, ale i aplikacyjną. I ta druga funkcja, w opinii Profesora, jest bodaj ważniejsza. W tym miejscu należy skonstatować, że prace naukowe tego uczonego spełniały wszystkie te kryteria. Jaki był Profesor Majorek w życiu codziennym? W pamięci uczniów i współpracowników zapisał się jako niezwykły uczony i znakomity, przyjazny człowiek w życiu codziennym. Był bowiem człowiekiem prawym i pogodnym, chętnie spieszącym z pomocą i radą. Trzeba się zgodzić z opinią Czesława Nowarskiego, który napisał że „posiadał przy tym komunikatywną osobowość, poczucie humoru i mądre podejście do codziennych problemów" (Nowarski 2003: 315).

Znakomitym nauczycielem i uczonym był ojciec Profesor Ludwik Grzebień SJ (1939-2020). Znakomity i zasłużony badacz dziejów. Bogactwo osobowości o. Grzebienia, dorobku naukowego, zasad pracy naukowej i sposobów nauczania opisali m.in. jego współpracownicy związani z Katedrą Historii Oświaty i Wychowania Akademii Ignatianum w Krakowie (Królikowska, Topij-Stempińska, Bieś 2020: 144-159). Najbliższy długoletni współpracownik Mistrza Ludwika, jak mówiło wielu współpracowników, o. Andrzej Bieś SJ, podejmując się stworzenia wizerunku o. Grzebienia jako nauczyciela akademickiego i uczonego, napisał: „Z ojcem Ludwikiem nieodmiennie kojarzą mi się takie terminy, jak błyskotliwość i pracowitość. Pracowitość wyrażająca się godzinami spędzonymi na zbieraniu i porządkowaniu materiałów źródłowych. Zadziwiająca swoboda i pewność z jaką poruszał się po kilometrach dokumentacji, głównie rękopiśmiennej i łacińskojęzycznej, utrwalonej na papierze, 
reprografowanej na fotokopiach, mikrofilmach lub nośnikach cyfrowych, była efektem lat poświęconych na ich fizyczne sortowanie i zabezpieczanie, połączonych $z$ intelektualnym wysiłkiem rozpoznawania i systematyzacji. Zdobytą w ten sposób wiedzę porządkował i upowszechniał w postaci katalogów, indeksów, inwentarzy, a przed wszystkim słowników i encyklopedii" (Bieś, Wspomnienie). Będąc na co dzień z o. Ludwikiem, o. Bieś dostrzegał, że tworząc różne projekty naukowe potrafił „wokół takich osobistych projektów naukowych zawsze skupić grono współpracowników, powierzając ukierunkowujące zadania, ale jednocześnie pozwalając na samodzielne zdobywanie warsztatowych doświadczeń" (Bieś, Wspomnienie). Ze współpracy z o. Grzebieniem zapamiętał wiele zasad, ale głównie to, że był to mistrz, który „swoją postawą uczył szacunku do źródła, które nie jest dane tylko do jednorazowego wykorzystania, ale może i powinno być używane w zróżnicowanych podejściach badawczych, a także otwarte i dostępne różnorodnym interpretacjom. Błyskotliwość o. Ludwika wyrażała się i w dowcipnych uwagach rzucanych od niechcenia, i w natychmiastowym dostrzeganiu słabych lub słabo udokumentowanych stron wywodu, i w przenikliwym proponowaniu zmian czy uzupełnień, które z niespójnego zarysu dobrych intencji potencjalnych autorów (np. prac dyplomowych) pozwalały wydobyć plan jasny, przejrzysty, zrozumiały i pełny" (Bieś, Wspomnienie).

Anna Królikowska, studentka o. Grzebienia, podkreśliła w swych wspomnieniach, że był Mistrzem, który pozwalał uczniom się rozwijać, stosując zasady, które opisała następująco: „Wierzył w swoich uczniów, ale im nie pobłażał, nie przytakiwał po to tylko, żeby ich nie urazić. Jego krytyka była wyzwalająca, otwierająca na nowe możliwości. Pozostawiał przestrzeń wolności i cieszył się z każdego sukcesu uczniów. Dostrzegałam w nim autorytet duchowy i intelektualny. Był erudytą, a jego erudycja budziła zachwyt i zdumienie. Jednocześnie nie onieśmielał i nie zawstydzał. Zawsze można było do niego przyjść i wychodziło się podniesionym na duchu" (Królikowska, Wspomnienie). W opisie osobowości o. Grzebienia jako mistrza-nauczyciela akcentowała, że chętnie pomagał wszystkim, którzy o pomoc naukową prosili: „Swojego potencjału nie zatrzymywał dla siebie, lecz był do dyspozycji innych. Zjeżdżali do niego ludzie z całej Polski i z innych krajów i nikt nie wychodził bez pomocy. Był człowiekiem 
głęboko życzliwym i bezinteresownym. Liczyła się dla niego nauka, dzięki której dochodzi się do prawdy" (Królikowska, Wspomnienie).

Z kolei Beata Topij-Stempińska, także studentka o. Ludwika, przypominając czas swoich studiów, stwierdzała, że przede wszystkim podziwiano go za wiedzę, erudycję i poczucie humoru. Jako pracownik naukowy Katedry Historii Oświaty i Wychowania AIK, dostrzegała w nim wiele cech znakomitego nauczyciela. Zawsze miał dużo cierpliwości i zrozumienia dla początkujących badaczy, nigdy nie odmawial przeczytania tekstu czy poczynienia uwag do projektów naukowych. Swoją wypowiedź o mistrzu Ludwiku zakończyła takimi słowami: „Nigdy nikomu nie odmówił pomocy w poszukiwaniach naukowych. Niezależnie czy pisał do niego magister, czy uznany profesor, zawsze służył radą, podpowiadał, rozwiewał wątpliwości, wskazywał istotne źródło. W innym człowieku zawsze widział człowieka. Był po prostu wyjątkowy, takich naukowców i dobrych ludzi rzadko się spotyka. Miałam wielkie szczęście i zaszczyt, że dane mi było poznać i pracować z Ojcem Profesorem" (Topij-Stempińska, Wspomnienie).

Z przywołanych przykładów mistrzów i ich działalności, tak naukowej jak i dydaktycznej, wypływa wiele istotnych zasad dla pełnienia tej tak ważnej roli w życiu naukowym i społecznym. Na tym etapie badań nie będę tworzyć listy tychże, mogę jedynie wypowiedzieć bardzo ogólny wniosek: być mistrzem, oznacza być człowiekiem kierującym się zasadami etyki, a jednym z jej przejawów jest rzetelność w nauce i dydaktyce.

\section{Rzetelność w nauce jako wartość i powinność mistrzów-nauczycieli}

Analizując źródła dotyczące działalności nauczycielskiej i naukowej wymienionych mistrzów-nauczycieli, można zauważyć, że powtarza się głównie jedna ważna idea, mianowicie rzetelność w pracy nauczycielskiej i badaniach naukowych oraz właściwa (rzetelna) ocena publikacji naukowych. Zagadnienie rzetelności w ocenie prac naukowych można opisać prezentując teoretyczne spojrzenie na to, czym jest recenzja pracy naukowej i jakie są zasady jej wykonywania oraz sygnalizując doświadczenia uczonych zawarte m.in. we wspomnieniach. 
O istocie i zasadach oceny prac naukowych pisał Lucjan Zarzecki prawie 100 lat temu w niezwykle ważnym artykule $O$ recenzjach $i$ recenzentach (Zarzecki 1923). Postulaty zawarte w jego rozważaniach nie tracą na wartości i także dzisiaj są aktualne. Przede wszystkim wskazał na przyczyny niewłaściwego podejścia do ocenianych publikacji prac naukowych wymieniając: (1) brak obiektywizmu, (2) nieumiejętność, (3) niesumienność i niezrozumienie znaczenia kulturalnego książki (Zarzecki 1923: 170). Wypowiadając się na temat braku obiektywizmu w ocenie publikacji naukowych, stwierdzał, że ma on różne przejawy, m.in. jest to: stronniczość, urzędowy purytanizm, brak zrozumienia merytorycznej strony pracy. $\mathrm{O}$ tym, co powinna dać czytelnikowi recenzja prac naukowych napisał: „Ocena powinna dać czytelnikowi przede wszystkim plastyczny obraz, jej szkic w głównych zasadniczych liniach. Bez tego jest dziełem bezużytecznym, chybionym. Krytyk w takim szkicu wykazuje, że pojął główną myśl, uchwycił jej główne linie przewodnie" (Zarzecki 1923: 170). Poruszył też kwestie, które nazwał zdolnością krytycyzmu autora recenzji, która jest połączona $\mathrm{z}$ analizą rzeczową i formalną pracy, a tej często w publikowanych recenzjach brak. Podniósł także istotne zagadnienie, jakim jest sumienność w recenzowaniu, która wymaga odwagi cywilnej, gdy wiemy, że autor ocenianej publikacji jest osobą znaczącą i wpływową. Uwagi w tej sprawie zakończył stwierdzeniem: „W każdej pracy potrzebna jest ta zasadnicza cnota: odwaga przekonań i spokojna ich obrona. Niesprawiedliwa chwalba tak samo jest szkodliwa jak niesłuszne skrytykowanie. Szkodliwa dla książki, dla autora jej i, co ważniejsza, dla dzieła kultury ogólnej” (Zarzecki 1923: 174). Odnosząc się w swych rozważaniach do praktyki podejmowania polemiki $\mathrm{w}$ recenzjach, podkreślił, że usposobienie polemiczne recenzenta winno się łączyć z odpowiedzialnością za dobro pracy i jej służyć, być przejawem wysokiej kultury umysłowej. Najważniejsza zasada, którą wskazywał w procesie wykonywania recenzji, brzmiała: dzieło oceniane powinno być rzetelnie przestudiowane. $Z$ tymi uwagami trzeba się zgodzić, bo wielu recenzentów współcześnie zarówno na poziomie wydawniczym, jak i w procesie awansów naukowych nie przestrzega tych zasad. Zamieszczane często na okładkach książek fragmenty recenzji są znakomitym dowodem, że niektórzy recenzenci nie zapoznali się z treścią opiniowanych książek. 
Z kolei przywoływany już Tadeusz Czeżowski jednym z wyznaczników etyki nauczycieli i badaczy nauki uczynił rzetelność. Według niego „rzetelność naukowa wymaga wolności w dwojakim znaczeniu: wolności wewnętrznej, tzn. siły do nieulegania żadnym pobudkom, aby sprzeniewierzyć się rzetelności za cenę powodzenia, sławy lub korzyści innego rodzaju; wolności zewnętrznej, tzn. wolności badań i krytyki naukowej, bez względu na interesy polityczne, ekonomiczne, wyznaniowe lub jakiekolwiek inne. Wolność wewnętrzną powinien uczony znaleźć w sobie; wolność zewnętrzną winny mu zapewnić społeczeństwo i państwo, w którym żyje. Wolność wewnętrzna ujawnia się w tym, że uczony jest w swych badaniach obiektywny, wolność zewnętrzna pozwala mu być bezstronnym" (Czeżowski 1958: 305-306). Było to przesłanie wypowiedziane ponad pół wieku temu, jednakże wciąż aktualne.

Kwestię pisania ocen i opinii prac naukowych poruszył Józef Pieter w publikacji pt. Autorskie kłopoty, odwołując się do własnego doświadczenia i tego, co nazywamy warsztatem naukowym każdego autora (Pieter 2019: 139-150, 206-214). Pieter stwierdzał, że obowiązki recenzenta należą do bardzo kłopotliwych zadań każdego pracownika naukowego. Jedną z trudniejszych kwestii był zdaniem tego uczonego obiektywizm w ocenie prac naukowych lub jego brak, a w przypadku recenzji awansowych zgodność ocen zawartych w treści recenzji z konkluzją tychże. Wymieniając zasady, którymi kierował się jako recenzent, zwrócił uwagę na kwestie dostrzeżonych błędów w pracach naukowych (Pieter 2019: 146-147) oraz określił sens ogólnej oceny prac i konkluzji recenzji czy opinii. Przede wszystkim wypowiedział sporo ważnych myśli dotyczących istoty właściwej oceny publikacji, stosunku recenzenta do dostrzeżonych błędów i wartości naukowej całej pracy: „Ostatecznie trudno chwalić to, czego nie ma. A «rozdmuchiwanie» wartości rzeczywistych ponad miarę uważam za niemoralne. Zgodnie $\mathrm{z}$ taką postawą wręcz potępiałem takich recenzentów, którzy «z igły robili widły», czy to w sensie pozytywnym czy negatywnym" (Pieter 2019: 147).

Mówiąc o doświadczeniach $\mathrm{w}$ zakresie oceny prac naukowych, warto przywołać przykłady z przeszłości dotyczące ocen prac z zakresu myśli pedagogicznej. Chodzi o oceny, które stały się powodem dyskusji między autorami (w wypadkach publikacji oceny tychże prac naukowych) a recenzentami. Echem w środowisku nie 
tylko pedagogów odbiła się dyskusja między Józefem Chałasińskim a Segriuszem Hessenem (Chałasińki 1938: 250-267; Hessen 1938: 228-248). Hessen w niezwykle krytycznej i obszernej recenzji, wręcz śmiem twierdzić napastliwej, poddał krytyce książkę Chałasińskiego pt. Szkota w spoteczeństwie amerykańskim $(1936)^{12}$. Kwestionował ujęcie wielu kategorii pedagogicznych, dodając przy tym swoje rozumienie i tytuły własnych prac, w których - jak stwierdzał - analizuje je, a także innych autorów, których rzekomo nie uwzględniono w tej pracy. W recenzji tej Hessen nie dostrzegł nic pozytywnego w pracy Chałasińskiego, jego zdaniem praca nie ma nic wspólnego z nauką. Dla celów polemicznych popełnił liczne błędy w interpretacji treści książki. Chałasiński w wymownie zatytułowanej odpowiedzi pt. Mowa tronowa Profesora Sergiusza Hessena podjął dyskusję z autorem recenzji, przy czym w prześmiewczym tonie zauważył, że recenzent chciał udowodnić, że on jako autor jest durniem. Podkreślił także brak szacunku recenzenta do prac polskich pedagogów oraz brak rozumienia metody naukowej. Ową recenzję nazwał „manifestem do wiernych" i próbą wskazania, gdzie ,jest tron polskiej pedagogiki” i kto go zajmuje. Podał również przykłady błędnej interpretacji przez Hessena koncepcji wychowania w społeczeństwie amerykańskim i przytaczanych teorii oraz odrzucił próby imputowania mu jako autorowi książki zarzutu socjologizmu.

Innym przykładem odnoszącym się do kwestii zasad oceniania prac naukowych była dyskusja między Bogdanem Nawroczyńskim a Władysławem Radwanem. Została opublikowana na łamach „Przeglądu Pedagogicznego”, a dotyczyła oceny publikacji Radwana pt. Postulaty w sprawie ustroju szkolnictwa w Rzeczypospolitej Polskiej (1925) (zob. Nawroczyński 1926; Radwan 1926)13. Nie wnikając w szczegóły tej dyskusji, można w dużym skrócie stwierdzić, że Nawroczyński oceniając publikacje Radawana zwrócił uwagę na niewłaściwe rozumienie terminu ,inteligencja”, używanego w kontekście reform oświatowych i w ogóle organizacji zasad edukacji, słowem - organizacji kształcenia inteligencji. Nawroczyński jako

12 Stwierdzam, że recenzja Hessena była napastliwa, ponieważ zarówno język krytyki, jak i podawane argumenty oraz odniesienia do literatury pozostawiały wiele do życzenia w kontekście kultury akademickiej i dyskursu. Zresztą także inne prace oceniane przez Hessena niekiedy miały taki wydźwięk.

13 Szerzej o tej sprawie zob. Jaroszuk (2004: 65-67). 
znawca problematyki zakwestionował poglądy autora Postulatów w sprawie ustroju szkolnictwa. W obszernej odpowiedzi Radwan nie tylko odrzucił wszelkie uwagi Nawroczyńskiego, ale i uznał, że jest to atak na jego osobę. W odpowiedzi na zarzuty Nawroczynski dokonał - jak napisał - kolejny raz wnikliwej analizy publikacji i podtrzymał swoje uwagi krytyczne, a odpowiadając na replikę Radawana dodał: „Do wystąpienia przeciwko książce p. Radwana skłoniło mnie przekonanie, że bez zdrowej i wysoce kulturalnej inteligencji nie masz ani cywilizowanego społeczeństwa, ani w demokracji” (Nawroczyński 1926: 43).

Nadmienić trzeba, że i współcześnie pojawiają się głosy mówiące o słabości krytyki naukowej. Niech przykładem będzie wypowiedź Tadeusza Lewowickiego (2006: 197-199). Słabość krytyki naukowej Lewowicki łączy z awansami naukowymi, podkreślając, że „ważną powinnością społeczności akademickiej jest dbałość o poziom prac naukowych oraz o przestrzeganie norm etyki zawodowej" (Lewowicki 2006: 197).

Bez wątpienia rzetelność $\mathrm{w}$ ocenie prac naukowych jest przejawem mistrzostwa i powinnością mistrzów-nauczycieli. Mówiąc o rzetelności w ocenie prac naukowych, należy podkreślić, że nie jest to sprawa łatwa, ale jest ona (rzetelność) powinnością każdego nauczyciela. $Z$ jednej strony rzetelność w ocenie prac naukowych jest drogą do mistrzostwa tych, którzy są poddawani ocenie, a z drugiej powinnością tych, którzy oceniają, czyli mistrzów-nauczycieli.

\section{Uwagi końcowe}

Przejawy zainteresowania przeszłością lokujące się w pedeutologii historycznej, zawarte $\mathrm{w}$ analizowanej literaturze głównie pamiętnikarskiej, są dowodem, że ten rodzaj spuścizny jest ważnym materiałem dla nauk o wychowaniu współcześnie i w ogóle dla edukacji nauczycieli na wszystkich poziomach kształcenia oraz edukacji w zakresie przygotowania do badań naukowych. Przywołując tutaj tytuł jednej z książek Marcina Kuli, można stwierdzić, że „przeszłość to spadek nie do odrzucenia" (Kula 2001). Spadek odziedziczony po mistrzach-nauczycielach jest w mojej opinii niezwykle cenny, jest właśnie spadkiem nie do odrzucenia. 
Warto więc zapytać, co wynika dla współczesnej nauki i krytyki naukowej $\mathrm{z}$ nakreślonych i zapamiętanych obrazów mistrzów-nauczycieli i ich spuścizny? Oto kilka uwag podsumowujących. Przywołany na wstępie tekstu cytat Byrona L. Sherwina, który wyraża istotę nauczycielskiego i mistrzowskiego wpływu na niego Abrahama Joshuy Heschela, pokazuje, że spotykamy wielu nauczycieli, ale mistrza, tego prawdziwego - tylko jednego. Osobiście zgadzam się z tym stwierdzeniem, co potwierdzają moje analizy różnorodnych źródeł $\mathrm{z}$ zakresu pedeutologii historycznej, a także własne doświadczenie. Przytoczone przykłady poglądów, zwłaszcza uczniów, na temat mistrzów-nauczycieli, zawarte w przywołanych źródłach i w opisie ich działalności nauczycielskiej, dowodzą jak ważna (w byciu mistrzem) jest jedność nauczania i badania. Ponadto w źródłach tych zostały zobrazowane nie tylko postawy mistrzów w nauce, ale i w ich życiu codziennym, i w tym zakresie także można mówić o jedności wszystkich sfer życia mistrzów. $Z$ analizy wykorzystanych źródeł można wyprowadzić kilka ważnych postulatów dotyczących bycia mistrzem-nauczycielem i pracownikiem naukowym oraz wynikających $\mathrm{z}$ tego faktu powinności. Trzeba jednak podkreślić, że każdy $\mathrm{z}$ wymienionych mistrzów zostawił nieco inną spuściznę, która wynika chociażby $\mathrm{z}$ innych zainteresowań naukowych i pełnionych funkcji w życiu organizacyjno-naukowym. Jednak wszyscy wymienieni uczeni swym życiem dowodzą konieczności pielęgnowania szacunku do uprawianej dyscypliny, wyrażającego się w procesie nauczania i sumienności w prowadzeniu badań naukowych. Poza dyskusją pozostaje najważniejszy postulat, który musi być realizowany przez mistrzów i nie traci na wartości także współcześnie - jest to rzetelność w nauce i nauczaniu. Istotę rzetelności można opisać słowami Tadeusza Czeżowskiego, który twierdzil, że ,jest ona przeciwieństwem brakoróbstwa, partactwa, oszustw wszelkiego rodzaju - ale także niedbalstwa, lenistwa, lekkomyślności i lekceważenia obowiązków, gonienia za korzyścią najniższym kosztem. W myśl postulatu rzetelności pracownik naukowy, czy to jako badacz, czy jako nauczyciel, jest obowiązany do standardu odpowiadającego w pełni wymaganiom metody naukowej, bez względu na cele uboczne. Metoda zaś naukowa $\mathrm{z}$ kolei koncentruje się dokoła dwóch zasad naczelnych: 1) dokładnego, jasnego, ścisłego formułowania wypowiedzi, tak by nie dopuszczały dwuznaczności, 2) należytego uzasadniania 
głoszonych twierdzeń" (Czeżowski 1967: 118). Te postulaty spełniali wymienieni w tekście mistrzowie-nauczyciele.

W kontekście przytoczonych ważnych idei mistrzostwa w nauce i nauczaniu, a zapisanych w biografiach naukowych, warto odnieść się do współczesności i braku przestrzegania wielu z nich. Brak rzetelności w ocenie prac naukowych, a tym samym w potwierdzaniu lub negowaniu spełnienia kryteriów awansu naukowego, wynika z różnych przyczyn. Brak rzetelności w pracach naukowych sprzyja słabości krytyki naukowej. Współcześnie najczęściej popełnianym błędem w tym zakresie jest ocena prac naukowych przez recenzentów, którzy nie znają ocenianego problemu. W tym negatywnym w skutkach dla nauki procesie swój udział mają nie tylko recenzujący, ale i śmiem twierdzić, że także sami autorzy prac, którzy niekiedy o takich recenzentów zabiegają lub godzą się na ich wyznaczanie, chociaż mają wpływ na ich wybór. Mowa o recenzentach wydawniczych publikowanych prac naukowych. Znane są przypadki autorów, którzy niemal wszystkie swoje prace mają opiniowane dla wydawnictw przez tych samych recenzentów. I nie byłoby w tym nic złego, gdyby owi recenzenci byli specjalistami w opiniowanej problematyce. $Z$ analizy tychże publikacji wynika, że tematycznie różnią się one pod względem źródeł, przyjętych metod ich analizy, a w konsekwencji znaczenia dla nowych ustaleń. Nie jest prawdą, że każdy samodzielny pracownik może recenzować każdą pracę. Przypisywanie sobie przez niektórych recenzentów wydawniczych prawa do oceny każdej pracy świadczy o braku odpowiedzialności za oceniane prace naukowe, jak i za dalszy los autora ocenianej pracy. Rzetelność w ocenie prac naukowych to powinność, ale i droga do mistrzostwa. Warto o tym pamiętać. Dobry przykład w tym zakresie dają nam przywołani w niniejszym tekście mistrzowie.

\section{Bibliografıa}

\section{Źródła archiwalne:}

Archiwum PAN, Warszawa, sygn. III-213, Spuścizna B. Nawroczyńskiego, j. $24-25,29$. 


\section{Literatura pamię̨nikarska:}

Kupisiewicz C. (2009). Okruchy moich wspomnień. Retrospektywny wybór wydarzeń z lat 1929-2009, Sosnowiec: Oficyna Wydawnicza Humanitas.

Majorek C. (1987). Przezwyciężenie diaspory. Wspótczesne tendencje w rozwoju historii wychowania, „Zeszyty Naukowe Uniwersytetu Jagiellońskiego. Prace Pedagogiczne nr 6", s. 177-190.

Majorek C. (1993). Glosa do rozważań o historii wychowania, „Kwartalnik Pedagogiczny", nr 2, s. 111-124.

Majorek C. (2002). Najnowsza historia wychowania wobec potrzeb pedagogiki, [w:] Edukacyjne drogi i bezdroża, red. R. Kwiecińska, S. Kowal, Kraków: Wydawnictwo Naukowe Akademii Pedagogicznej, s. 45-60.

Mrozowska K. (1984). Charakter i szkolny kotnierzyk, [w:] Z. Szlachta, Mistrz, Warszawa: Młodzieżowa Agencja Wydawnicza, s. 57-69.

Nowarski C. (2003). Pamięci prof. zw. dra hab. Czestawa Majorka (27 IX 1938 - 29 IX 2002), „Annales Universitatis Paedagogicae Cracoviensis. Studia Historica II. Folia 17”, s. 311-314.

Szczepański W. (1994). Mistrz i nauczyciel, „Czasopismo Zakładu Narodowego im. Ossolińskich”, t. 4, s. 155-160.

Szlachta Z. (1984). Mistrz, Warszawa: Młodzieżowa Agencja Wydawnicza.

\section{Wspomnienia:}

- o. dr hab. Andrzej Paweł Bieś, prof. AIK

- dr hab. Anna Królikowska, prof. AIK

- s. dr hab. Maria Opiela, prof. KUL

- dr hab. Beata Topij-Stempińska, prof. AIK

Teksty wspomnień w posiadaniu autorki artykułu.

\section{Opracowania i źródła drukowane:}

Bartnicka K. (2002). Kamila Mrozowska (28 I 1917 - 2 V 2002), „Rozprawy z Dziejów Oświaty", nr 41, s. 3-5.

Chałasiński J. (1938). Mowa tronowa prof. Sergiusza Hessena. Rozprawa sukcesyjna z powodu niebezpieczeństwa grożacego pedagogice, „Przegląd Socjologiczny", t. 6, nr 1-2, s. 250-267.

Czeżowski T. (1958). O rzetelności, obiektywności i bezstronności w badaniach naukowych, [w:] tegoż, Odczyty filozoficzne, Toruń: Towarzystwo Naukowe, s. 305-309.

Czeżowski T. (1967). W sprawie deontologii pracownika naukowego, „Etyka”, nr 2, s. 111-121.

Dybiec J. (1999), Profesor Kamilla Mrozowska, „Biuletyn Historii Wychowania", nr 9-10, s. 39-42. 
Gadamer H.-G. (2011). O skrytości zdrowia, przeł. A. Przyłębski, Poznań: Wydawnictwo „Media Rodzina”.

Hessen S. (1938). O niebezpieczeństwie socjologizmu w pedagogice, „Przegląd Socjologiczny”, t. 6, nr 1-2, s. 228-248.

Jadacki J.J. (2016). Mistrz i uczeń, „Edukacja Filozoficzna”, s. 77-81, http:// www.edukacja-filozoficzna.uw.edu.pl/index_pliki/efspec/08.\%20Jadacki.pdf [dostęp 10.02.2021].

Jadczak R. (1997). Mistrz i jego uczniowie, Warszawa: Wydawnictwo Naukowe Scholar.

Jadczak R. (red.) (1992). Kazimierz Twardowski. Wybór pism psychologicznych i pedagogicznych, Warszawa: Wydawnictwa Szkolne i Pedagogiczne.

Jaroszuk T. (2004). Z iskra filareckq w oku. Świat i dzieto B. Nawroczyńskiego, Olsztyn: Wydawnictwo Uniwersytetu Warmińsko-Mazurskiego.

Kaismow H., Sherwin B.L. (red.) (2005). Żadna religia nie jest samotna wyspa. Abraham Joshua Heschel $i$ dialog międzyreligijny, przeł. M. Kapera, Kraków: Wydawnictwo WAM.

Karolewicz G. (2020). Mistrzowie we wspomnieniach swoich uczniów. Kartka z dziejów Katolickiego Uniwersytetu Lubelskiego, Lublin: Wydawnictwo KUL.

Królikowska A., Topij-Stempińska B., Bieś A.P. (2020). Ksiąz Profesor Ludwik Grzebień SJ (1939-2020). Mistrz w stużbie nauki, „Przegląd Historyczno-Oświatowy”, nr 3-4, s. 144-159.

Kula M. (2001). Przesztość: spadek nie do odrzucenia, Poznań: Poznańskie Towarzystwo Przyjaciół Nauk.

Kupisiewicz C. (2010). Bogdan Nawroczyński w świetle opracowań leksykograficznych, [w:] Życie i dzieto Profesora Bogdana Nawroczyńskiego wybitnego Zagtębianina. W osiemdziesiata rocznice publikacji "Zasad nauczania”, Sosnowiec: Oficyna Wydawnicza Humanitas, s. 13-14.

Kurdybacha Ł. (1947). Wspomnienie o Stanistawie Eempickim. (Przemówienie na posiedzeniu Towarzystwa Literackiego im. Mickiewicza w Krakowie, $w$ dniu 31. I. 1948), „Pamiętnik Literacki”, t. 37, s. 367-379.

Lewowicki T. (2006). List otwarty w sprawie stabości krytyki naukowej i negatywnych zjawisk w postępowaniach awansowych, „Kultura i Edukacja”, nr 2-3, s. 197-199.

Marynowicz- Hetka E. (wyb. i oprac.) (1997). Mistrz - uczeń. Wyobrażenia czy rzeczywistość, czyli o tworzeniu szkót naukowych, Łódź: Łódzkie Towarzystwo Naukowe.

Nawroczyński B. (1926). Odpowiedź na replikę p. Wt. Radwana, „Przegląd Pedagogiczny", nr 2, s. 41-43.

Opiela M. (2018). Teresa Kukotowicz (1925-2014) jako nauczyciel akademickimistrz i wychowawca, [w:] Nauczyciele. Zastużeni-niedocenieni-zapamiętani, red. W. Szulakiewicz, Toruń: Wydawnictwo Naukowe Uniwersytetu Mikołaja Kopernika, s. 97-116.

Pieter J. (2019). Autorskie ktopoty, Warszawa: Wydawnictwo Naukowe PWN. 
Radwan W. (1925). Postulaty w sprawie ustroju szkolnictwa w Rzeczypospolitej Polskiej, Warszawa-Łódź: Nasza Księgarnia.

Radwan W. (1926). O ustrój naszego szkolnictwa, „Przegląd Pedagogiczny”, nr 1, s. 39-42 i nr 2, s. 8-10.

Rowid H. (1957). Podstawy i zasady wychowania, Warszawa: Wydawnictwo Oświatowe.

Ruta Z. (2003). In memoriam, [w:] W stużbie szkoty i nauki. Księga pośrwięcona Profesorowi Czestawowi Majorkowi, red. Z. Ruta, R. Ślęczka, Kraków: Wydawnictwo Naukowe Akademii Pedagogicznej.

Ruta Z. (2008). Majorek Czestaw, [w:] Stownik biograficzny polskiej historii wychowania, red. W. Szulakiewicz, A. Meissner, Toruń: Wydawnictwo Adam Marszałek, s. 527-535.

Sherwin B.L. (2005). Mój Mistrz, [w:] H. Kasimow, B.L. Sherwin (red.), $\dot{Z}$ adna religia nie jest samotnq wyspa. Abraham Joshua Heschel $i$ dialog międzyreligijny, przeł. M. Kapera, Kraków: Wydawnictwo WAM, s. 69-90.

Szulakiewicz W. (2008). Kamilla Mrozowska o wartości poznania przesztości oświatowo-wychowawczej, [w:] Historia, mentalność, tożsamość. Miejsce i rola historii oraz historyków w życiu narodu polskiego i ukraińskiego w XIX i XX wieku, red. J. Pisulińska, P. Sierżęga, L. Zaszkilniak, wstępem opatrzył J. Maternicki, Rzeszów: Wydawnictwo Uniwersytetu Rzeszowskiego, s. 658-671.

Szulakiewicz W. (2010). Za przyktadem mistrza. Tadeusza Czeżowskiego (1889-1981) stużba uniwersytetowi i nauce, „Rozprawy z Dziejów Oświaty", t. 47, s. 109-127.

Szulakiewicz W. (2012). Stanistaw Eempicki (1886-1947). Twórca lworwskiej szkoty historii wychowania, Torun: Wydawnictwo Naukowe Uniwersytetu Mikołaja Kopernika.

Szulakiewicz W. (2013). Być nauczycielem akademickim. Rozważania Hansa-Georga Gadamera (1900-2002), „Rozprawy z Dziejów Oświaty”, t. 50, s. $65-79$.

Szulakiewicz W. (2014a). O uczacych i uczonych. Szkic z pedeutologii historycznej, Toruń: Wydawnictwo Naukowe Uniwersytetu Mikołaja Kopernika.

Szulakiewicz W. (2014b). Nauczyciel w twórczości i dziatalności pedagogicznej Kazimierza Twardowskiego, „Przegląd Historyczno-Oświatowy”, nr 1-2, s. 5-19.

Szulakiewicz W. (2017). Bogdana Nawroczyńskiego (1882-1974) zastugi w awansie akademickim pedagogiki. Opiniotwórczy gtos uczonego, „Przegląd Historyczno-Oświatowy", nr 3-4, s. 88-104.

Szulakiewicz W. (2018). Nauczyciel jako „wspóttwórca” drugiego cztowieka. Inspiracje filozofii spotkania Andrzeja Nowickiego (1919-2011), [w:] Nauczyciele. Zastużeni - niedocenieni - zapamiętani, red. W. Szulakiewicz, Torun: Wydawnictwo Naukowe Uniwersytetu Mikołaja Kopernika, s. 67-80. 
Śródka A. (red.) (1994-1998). Uczeni Polscy XIX i XX wieku, t. 1-4, Warszawa: Aries.

Wiloch T. (1996). Wymagat tylko(?) rzetelności naukowej, [w:] Bogdan Nawroczyński. Uczony - bumanista - wychowawca, red. A. Mońka-Stanikowa, S. Mieszalski, A.A. Kotusiewicz, Warszawa: Wydawnictwo Akademickie „Żak”, s. 129-133.

Woleński J. (1985). Filozoficzna szkota lwowsko-warszawska, Warszawa: Państwowe Wydawnictwo Naukowe.

Wołoszyn S. (1998). Pedagogiczne wędrówki przez wieki i zagadnienia. Studia i szkice, red. Z. Żukowska, Toruń: Wydawnictwo Adam Marszałek.

W stużbie szkoty i nauki. Księga poświęcona Profesorowi Czestawowi Majorkowi, red. Z. Ruta, R. Ślęczka (2003). Kraków: Wydawnictwo Naukowe Akademii Pedagogicznej.

Zarzecki L. (1923). O recenzjach i recenzentach „Przegląd Pedagogiczny”, nr 3, s. 169-175.

Zgorzelski C. (1983). Mistrzowie i ich dzieła, Kraków: Znak.

\section{ADRES DO KORESPONDENCJI}

Prof. dr hab. Władysława Szulakiewicz

Uniwersytet Mikołaja Kopernika w Toruniu

Instytut Nauk Pedagogicznych

e-mail: jszulak@umk.pl 